\title{
Yeni Tip Koronavirüs (COVID-19) Pandemisi Bilgi ve Korunma Yolları Hakkında Sag̃lık Teknikeri Adaylarının Farkındalık Düzeyleri
}

\section{Awareness Levels of Health Technician Candidates About the Knowledge and Prevention Ways of the New Type Coronavirus (COVID-19) Pandemic}

\author{
Elif Burcu BALi'(iiD), Tug̃çe Deniz TANALP2(ID), İsmet ÇELEBi²(ID)
}

\footnotetext{
${ }^{1}$ Gazi Üniversitesi Sag̃ılık Hizmetleri Meslek Yüksekokulu, Tıbbi Hizmetler ve Teknikler Bölümü, Tıbbi Laboratuvar Teknikleri Programı, Ankara, Türkiye

${ }^{2}$ Gazi Üniversitesi Sag̃lık Hizmetleri Meslek Yüksekokulu, Tıbbi Hizmetler ve Teknikler Bölümü, illk ve Acil Yardım Programı, Ankara, Türkiye
}

Makale atıfı: Bali EB, Tanalp TD, Çelebi I. Yeni tip koronavirüs (COVID-19) pandemisi bilgi ve korunma yolları hakkında sağlık teknikeri adaylarının farkındalık düzeyleri. FLORA 2021;26(1):67-77.

\section{ÖZ}

Giriş: Dünya Sağlık Örgütü, Çin'in Wuhan şehrinde Aralık 2019'da yeni tanımlanan bir $\beta$-koronavirüsün neden olduğu hastalı̆ı pandemik olarak ilan etmiş ve koronavirüs hastalığı 2019 (COVID-19) olarak adlandırmıştır. Sağlık çalışanlarının COVID-19 ile ilgili bilgi, davranış ve tutumlarına yönelik farkındalıkları bu pandemik hastalığa etkili çözüm bulabilmede hayati önem taşımaktadır. Bu nedenle bu çalışmada, sağlık teknikeri adaylarının COVID-19 bilgi ve korunma yolları hakkındaki farkındalık düzeylerinin belirlenmesi amaçlanmıştır.

Materyal ve Metod: Araştırmaya Gazi Üniversitesi Sağlık Hizmetleri Meslek Yüksekokulu'nda okuyan toplamda 906 sağlık teknikeri adayı katılmıştır. Literatüre göre hazırlanmış anket formu adaylara e-posta yoluyla gönderilmiş ve adaylardan gönüllü olarak anketi yanıtlamaları istenmiştir. Veriler Ki-kare, Mann Whitney U ve korelasyon testleriyle analiz edilmiştir.

Bulgular: Araştırma bulgularında, COVID-19 dünyada alınan önlemlere karşı endişe düzeyi ile COVID-19 endişe düzeyi arasında pozitif yönlü orta düzeyde $(r=0.512, p=0.000)$ korelasyon tespit edilmiştir. COVID-19'a karşı dünyada alınan önlemler, birinci sınıf öğrencilerinde, COVID-19 bilgi puanları sağlık meslek lisesi mezunlarında, hastalıktan korunma yolu puanları ise kadınlarda daha yüksek ve istatistiksel olarak anlamlı bulunmuştur $(p<0.05)$. Dünya'da ve Türkiye'de COVID-19'a karşı alınan önlemlerin yeterliliği ve bilgi puanları programlara göre anlamlı farklıık $(p<0.05)$ göstermiştir.

Sonuç: Bu araştırmanın sonucunda, sağlık teknikeri adaylarııın COVID-19 hakkında iyi bir bilgi düzeyine sahip oldukları ve mevcut pandemik hastalık için alınması gereken önlemlerle ilgili yüksek farkındalıkları olduğu belirlenmiştir. Buna ilaveten, adayların COVID19 ile ilgili endişe düzeyleri özellikle kronik hastalığı olanlarda ve kadınlarda daha fazla bulunmuştur. Adaylar hastalıkla ilgili endişeli olmalarına rağmen, Türkiye'de alınan önlemleri dünyada alınan önlemlerden daha yeterli bulmuştur. Bu açıdan adaylar ülkemizin sağlık politikalarına ve pandemi ile ilgili ülkemizde alınan önlemlere güven duymaktadır. Sonuç olarak, bu araştırma pandemik hastalıklara yönelik önlem alabilmek ve çözüm üretebilmek için Türkiye'de daha kapsamlı farkındalık çalışmalarının yapılması gerektiğini ortaya koymaktadır.

Anahtar Kelimeler: COVID-19; Koronavirüs; Pandemik; Farkındalık 


\title{
ABSTRACT \\ Awareness Levels of Health Technician Candidates About the Knowledge and Prevention Ways of the New Type Coronavirus (COVID-19) Pandemic
}

\author{
Elif Burcu BALi', Tug̃çe Deniz TANALP², ismet ÇELEBi ${ }^{2}$
}

\footnotetext{
${ }^{1}$ Department of Medical Services and Techniques, Gazi University Health Services Vocational School, Programme of Medical Laboratory Techniques, Ankara, Turkey

${ }^{2}$ Department of Medical Services and Techniques, Gazi University Health Services Vocational School, Programme of Paramedic, Ankara, Turkey
}

Introduction: World Health Organization declared a disease as pandemic caused by a newly identified $\beta$-coronavirus, and named it as the coronavirus disease 2019 (COVID-19). The awareness of health workers about their knowledge, behavior, and attitudes about COVID-19 is vital to find an effective solution to this pandemic disease. Therefore, in this study, it was aimed to reveal the awareness levels of health technician candidates about the knowledge and prevention ways of COVID-19.

Materials and Methods: A total of 906 health technician candidates studying at Gazi University participated in the study. A questionnaire form prepared according to the literature was sent to the candidates via e-mail. The data were analyzed using Kruskal Wallis, Mann Whitney $U$, and correlation tests.

Results: A moderate positive correlation ( $r=0.512, p=0.000)$ was determined between the anxiety level of COVID-19 and the anxiety level of COVID-19 against the precautions taken by the world. The precautions in the world in first-year students, the scores of knowledge in graduates, and disease prevention ways in women were found to be higher $(p<0.05)$. The precautions sufficiency in the world and in Turkey and the scores of knowledge were significantly $(p<0.05)$ different among the programs.

Conclusion: Health technicians candidates had a good level of knowledge about COVID-19 as well as a high awareness of the precautions to be taken for the current pandemic disease. Moreover, candidates' anxiety levels were found to be high, in particular of those with chronic diseases and the female gender. Despite being worried about the disease, candidates found the precautions taken by Turkey more sufficient than the world. In this respect, the candidates trust their country's health policies. Consequently, this study revealed that the investigations about awareness should be carried out more comprehensively in Turkey to take precautions and to produce solutions for pandemic diseases.

Key Words: COVID-19; Coronavirus; Pandemic; Awarenes

\section{GiRiș}

Coronaviridae familyasının Coronavirus cinsine ait olan koronavirüsler, insanlarda ve cesitli hayvanlarda bulunan zoonotik patojenler olup, pleomorfik, karakteristik olarak tac seklinde, 80160 nM boyutunda ve tek iplikli zarfl RNA virüsleridir. Bunlar bilinen RNA virüsleri arasında en genis genoma sahip olup, mutasyon oranları, genomlarındaki transkripsiyon hatalarının sık gelișmesinden dolayı cok yüksektir ${ }^{[1,2]}$. Çin'in Wuhan sehrinde 12 Aralık 2019'da yeni tanımlanan bir $\beta$-koronavirüsün pnömoni vakalarına neden olduğu bildirilmiștir. Bu koronavirüs, Dünya Sağllk Örgütü (DSÖ) tarafından bașlangıcta 2019-nCoV (2019-novel coronavirus), Uluslararası Virüs Taksonomi Komitesi tarafından ise SARS-CoV-2 (severe acute respiratory syndrome coronavirus-2) olarak adlandırmıs ve sonrasında DSÖ hastalığı virüsün neden olduğu hastalı COVID-19 (coro- navirus disease-2019) olarak tanımlamıstır ${ }^{[3]}$. Bu virüs, inhalasyon veya infekte damlacıklar ile temas yoluyla bulașmakta ve virüsün kuluçka süresi 2-14 gün arasında değișmektedir. Hastalığın semptomlarını ise genellikle ates, öksürük, boğaz ağrısı, nefes darlığı, yorgunluk ve halsizlik olușturmaktadır $^{[4]}$. Su ana kadarki verilerde, COVID-19 olgularında dünyada capında \%7 civarında ölüm oranı olduğu bildirilmiștir ${ }^{[5]}$. DSÖ 4.11 .2020 tarihli toplant1 raporunda ise; kümülatif olarak, dünya capında 46 milyondan fazla vaka, 1.2 milyon ölüm rapor edilmiș ve yakın zamandaki vaka artıșının büyük ölçüde Avrupa'da artan insidansa bağlı olduğu kaydedilmiștir ${ }^{[6]}$.

Her ülke içinde, belirli yerler veya hizmetler salgının odak noktası olabilmektedir. Sağlık hizmetleri hastanelerin yanı sıra acil klinikler, bakım evleri, toplum sağlığı merkezleri gibi hastane dıșında da sağlanmakta olup, buralarda çalıșan 
sağlık çalısanlarının infeksiyonlara maruz kalma ve infeksiyonu sağllklı insanlara bulaștırma riski oldukça yüksektir ${ }^{[7]}$. Bunun yanında, bașlangıçta Cin'de hiçbir sağlık çalıșanında hastalık görülmezken, 12.01.2020 sonrası hastaların \%7'sinin sağlık çalıșanı olduğu rapor edilmiștir ${ }^{[8]}$. COVID-19 pandemisinde diğer bulașıcı hastalıklarda olduğu gibi sağlık çalıșanları topluma göre yüksek düzeyde risk altında olup, COVID-19 pandemisine etkili cözüm bulabilmek için sağlık calıșanlarının ve sağlık çalısanı olmaya aday bireylerin hastalık ile ilgili bilgi, davranıș ve tutumlarına yönelik farkındalıkları büyük bir önem tașımaktadır. Bu nedenle bu çalıșmada, ileride sağlık personeli olarak görev yapacak olan sağlık teknikeri adaylarının COVID-19 pandemisi bilgi ve korunma yolları hakkındaki farkındalık düzeylerinin ortaya cıkarılması amaçlanmıștır.

\section{MATERYAL ve METOD}

$\mathrm{Bu}$ çalısma kesitsel tipte olup, araștırmanın çalıșma grubunu Gazi Üniversitesi Sağlık Hizmetleri Meslek Yüksekokulu'nda eğitim gören 1190 öğrenci olușturmuștur. Anket formuna yanıt veren öğrenci sayısı 1040 olup 134‘ü eksik veri olduğu için toplam 906 (ulașım oranı \%76.13) form çalıșmaya dahil edilmiștir. Calıșma öncesinde Gazi Üniversitesi Klinik Olmayan Araștırmalar Etik Kurulundan (Etik No: 2020-216) izin alınmıștır.

Araștırmada veri toplama aracı olarak araștırmacılar tarafından hazırlanan ve üc bölümden olușan anket formu kullanılmıștır. Anket formu Nisan-Mayıs 2020 tarihleri arasında e-posta yolu ile öğrencilerin mail adreslerine gönderilmiș ve öğrencilerden anketi doldurmaları istenmiștir. Anket formunda birinci bölümde katılımcılara yas, cinsiyet, öğrenim programı, yașanılan yer gibi sosyo demografik özellikler ve COVID-19 için alınan önlem yeterliliği, endișe düzeyleri ve bilgi-korunma yolunu ölçen 17 soru sorulmus, verilen doğru cevaplara göre bilgi ve korunma yolu puanları hesaplanmıstır. İkinci bölümde, literatüre göre hazırlanmıș COVID-19 hakkında genel bilgi ile ilgili 8 soru ve üçüncü bölümde COVID-19'a karș1 korunma yolları ile ilgili 9 soru sorulmustur. Anket soruları literatürden ve Sağlık Bakanlığı tarafından yayımlanan koronavirus rehberinden yararlanılarak hazırlanmıstır ${ }^{[7-12]}$. Anket formunda yer alan COVID-19 ile ilgili bilgi ve korunma yollarına ait sorular için öncelikle araștırmacılar tarafından ayrı ayrı soru havuzu olușturulmus ve bes uzman görüșü alınarak (iki mikrobiyolog, iki Türk dil uzmanı ve bir halk sağlığı uzmanı) benzer olan dört soru çkartılmıștır. Uzman görüsüunden sonra netleșen maddelerin doğru anlașılıp anlașılmadığını ölçmek için 10 üniversite öğrencisine veri formu mail atılarak pilot calıșma yapılmıștır ve pilot çalısma sonrasında herhangi bir soru çkartılmamıștır. Katılımcıların bu soruları doğru ya da yanlıs seklinde yanıtlaması istenmiștir. Yanlıs yanıtlanan her soru için bir puan, doğru yantlanan her soru için ise iki puan üzerinden değerlendirilmiș ve toplam bilgi ve toplam korunma yöntemi puanları hesaplanmıștır. Bu bağlamda bilgi puanı için en düșuik puan 8 , en yüksek puan 16 , korunma yöntemleri için en düșük puan 9, en yüksek puan 18'dir. Araștırmanın bağımlı değișkenlerini yeni tip koronavirüs ile ilgili bilgi ve tutum soruları, bağımsız değișkenlerini ise öğrenim görülen program, yas, cinsiyet, kronik hastalığın olup olmaması ve yeni tip koronavirüs ile ilgili endișe düzeyi olușturmuștur.

\section{İstatiksel Analiz}

Calıșmadan elde edilen veriler SPSS 22.0 programında değerlendirilerek, sağlık teknikeri adaylarının sosyo-demografik özelliklerine ilișkin dağılımları frekans ve yüzde değer olarak hesaplanmıstır. Verilerin Kolmogorov-Smirnov ve Shapiro-Wilk testi sonucunda normal dağılmadığı görülmüsstür ( $p<0.05)$. Adayların COVID-19 ile ilgili alınan önlem ve endișe düzeyleri ile bilgi ve korunma yolları arasındaki ilișki Sperman's rho testi ile belirlenmiștir. Korelasyon değerleri düsük (0-0.29), orta (0.30-0.69) ve yüksek (0.70-1) olarak sınıflandırmıstır ${ }^{[13]}$. Adayların COVID-19 bilgi ve korunma yolları ile ilgili sorulara vermiș olduğu yanıtlar demografik değișkenlere göre farklılıkları Ki-kare testi ile belirlenmistir. Katılımcıların COVID-19 endișe düzeyi ve alınan önlem yeterliliği ile ilgili düsüncelerine ait puanları ve demografik değiskenlere göre farklılık gösterme durumları parametrik olmayan Mann Whitney U testi kullanılarak saptanmıstır. Testlerde anlamlllık düzeyi olarak $* p<0.05$ kabul edilmiștir.

\section{BULGULAR}

Araștırmada sağlık teknikeri adaylarının sosyo-demografik özellikleri Tablo 1'de gösterilmiș olup, adayların yaș ortalamasının $20.12 \pm 1.99$ 
Tablo 1. Sağlık teknikeri adaylarının sosyo-demografik özellikleri

\begin{tabular}{|c|c|c|}
\hline Okuduğu Program & $\mathbf{n}$ & $\%$ \\
\hline Ağız ve diş sağlığı & 124 & 13.7 \\
\hline Patoloji teknikerliği & 137 & 15.1 \\
\hline İlk ve acil yardım & 143 & 15.8 \\
\hline Tıbbı dökümantasyon ve sekreterlik & 123 & 13.6 \\
\hline Tıbbi görüntüleme teknikerliği & 136 & 15.0 \\
\hline Tıbbi laboratuvar teknikerliği & 130 & 14.3 \\
\hline Yaşı bakım teknikerliği & 113 & 12.5 \\
\hline Sinif & & \\
\hline $\begin{array}{l}\text { Birinci sınıf } \\
\text { İkinci sınıf }\end{array}$ & $\begin{array}{l}487 \\
419\end{array}$ & $\begin{array}{l}53.8 \\
46.2\end{array}$ \\
\hline $\begin{aligned} \text { Yaş } & \\
& <20 \\
& \geq 21\end{aligned}$ & $\begin{array}{l}657 \\
249\end{array}$ & $\begin{array}{l}72.5 \\
27.5\end{array}$ \\
\hline $\begin{array}{l}\text { Mezun olunan lise } \\
\text { Sağlık meslek lisesi } \\
\text { Diğer liseler }\end{array}$ & $\begin{array}{l}517 \\
389\end{array}$ & $\begin{array}{l}57.1 \\
42.9\end{array}$ \\
\hline $\begin{array}{l}\text { Cinsiyet } \\
\text { Erkek } \\
\text { Kadın }\end{array}$ & $\begin{array}{l}172 \\
734\end{array}$ & $\begin{array}{l}19.0 \\
81.0\end{array}$ \\
\hline $\begin{array}{l}\text { Öğretim süresince ikamet edilen yer } \\
\text { Yurt } \\
\text { Öğrenci evi } \\
\text { Aile/akraba }\end{array}$ & $\begin{array}{c}468 \\
69 \\
369\end{array}$ & $\begin{array}{c}51.7 \\
7.6 \\
40.8\end{array}$ \\
\hline $\begin{array}{l}\text { Kronik hastalık durumu } \\
\text { Yok }\end{array}$ & 838 & 92.5 \\
\hline
\end{tabular}

Tablo 2. Sağlık teknikeri adaylarının COVID-19 için alınan önlem yeterliliği, endişe düzeyleri, bilgi ve korunma yolu puanları

\begin{tabular}{lcc} 
COVID-19 önlem yeterliliği ve endişe düzeyleri ile ilgili sorular & $\begin{array}{c}\text { Ortalama } \pm \\
\text { SS* Puan }\end{array}$ & $\begin{array}{c}\text { Miniumum-Maksimum** } \\
\text { Puan }\end{array}$ \\
\hline COVID-19 için dünya çapında alınan önlemler sizce yeterli mi? & $4.86 \pm 1.88$ & $1-10$ \\
COVID-19 için dünya çapında alınan önlemler sizi endişelendiriyor mu? & $6.65 \pm 2.33$ & $1-10$ \\
COVID-19 için ülkemizde alınan önlemler sizce yeterli mi? & $6.26 \pm 2.17$ & $1-10$ \\
COVID-19 için ülkemizde alınan önlemler sizi endişelendiriyor mu? & $5.76 \pm 2.46$ & $1-10$ \\
COVID-19 sizce ne kadar tehlikeli? & $8.03 \pm 1.91$ & $1-10$ \\
COVID-19 sizi ne kadar endişelendiriyor? & $7.27 \pm 2.33$ & $1-10$ \\
COVID-19 bilgi puanı & $32.37 \pm 4.68$ & $18-44$ \\
COVID-19 korunma yolu puanı & $45.35 \pm 5.10$ & $10-50$ \\
\hline
\end{tabular}

*SS: Standart Sapma, **Minimum-Maksimum.

(min: 17, max: 38) olduğu tespit edilmiștir. Adayların COVID-19 ile ilgili alınan önlem ve endise düzeyleriyle ilgili düșünceleri ise 10 puan üzerinden değerlendirilmiștir (Tablo 2). Katılımcıların
COVID-19 bilgi puan ortalamas1 40 üzerinden $32.37 \pm 4.68$, COVID-19 korunma yolları puan ortalamas1 ise 75 üzerinden $45.35 \pm 5.10$ bulunmustur. 


\begin{tabular}{|c|c|c|c|c|c|}
\hline & & $\begin{array}{l}\text { COVID-19 Dünyada } \\
\text { alınan önlemlere } \\
\text { karşı endişe düzeyi }\end{array}$ & $\begin{array}{l}\text { COVID-19 Türkiye'de } \\
\text { alınan önlemlere } \\
\text { karşı endişe düzeyi }\end{array}$ & $\begin{array}{c}\text { COVID-19 } \\
\text { endişe düzeyi }\end{array}$ & $\begin{array}{l}\text { COVID-19 } \\
\text { bilgi puanı }\end{array}$ \\
\hline \multirow{2}{*}{$\begin{array}{l}\text { COVID-19 Türkiye'de alınan } \\
\text { önlemlere karşı endişe düzeyi }\end{array}$} & $r$ & $.581^{\star *}$ & & & \\
\hline & $\mathrm{p}$ & .000 & & & \\
\hline \multirow[t]{2}{*}{ COVID-19 endişe düzeyi } & $r$ & $.512^{\star *}$ & $.405^{\star *}$ & & \\
\hline & $\mathrm{p}$ & .000 & .000 & & \\
\hline \multirow[t]{2}{*}{ COVID-19 bilgi puanı } & $\mathrm{r}$ & $.081^{*}$ & -.005 & $.082^{*}$ & \\
\hline & $p$ & .015 & .888 & .014 & \\
\hline \multirow[t]{2}{*}{ COVID-19 korunma puanı } & r & $.102^{* *}$ & .043 & $.139 * *$ & $.305^{* *}$ \\
\hline & $p$ & .002 & 199 & .000 & .000 \\
\hline
\end{tabular}

Tablo 3'e göre COVID-19 dünyada alınan önlemlere karș1 endișe düzeyi ile COVID-19 endișe düzeyi $(r=0.512, p=0.000)$ arasında pozitif yönlï orta düzey, COVID-19 bilgi puanı ve korunma yolları puanı arasında pozitif yönlü düșük düzeyde anlamlı ilișki $(r=0.305, p=0.000)$ saptanmıștır.

Tablo 4'e göre, COVID-19 bilgi sorularına doğru yanıt veren katılımclardan ikinci sınıfta öğrenim görenler, birinci sinıftakilere göre istatistiksel olarak anlaml ve yüksektir ( $p=0.003)$. COVID-19 kuluçka süresini $(p=0.000)$, hastalığın yașllarda daha ölümcül olduğunu ( $p=0.009$ ), en önemli belirtilerinin nefes darlığı ve öksürük olduğunu ( $p=0.025)$, virüsün damlacık yolu ile bulaștığını $(p=0.046)$ bilme oranı kadınlarda erkeklere göre istatistiksel olarak anlamlı ve yüksek bulunmuștur.

COVID-19 korunma yollarına yönelik sorular incelendiğinde, öksüreceğimiz ya da hapşıracağımız zaman tek kullanımlık mendil ya da kolumuzun ic yüzeyini kullanabiliriz $(p=0.012)$, ellerimizi yıkarken sabun kullanmasak da korunuruz $(p=0.018)$, kișisel hijyene dikkat etmek hastalıktan korunmada önemlidir $(p=0.000)$, temas edilen yüzeylerin dezenfeksiyonu virüsün yayılmasını engellemekte son derece önemlidir $(p=0.009)$, toplu tașıma araçlarının kullanımı yeni tip coronavirüs yayılımını arttırır $(p=0.033)$, yurt dișindan gelen kișilerin 14 gün evden dișarı cıkmaması yeni tip koronavirüs yayılımını engeller $(p=0.009)$, tokalașma ve sarılma gibi yakın temaslar koronavirüsün yayılımını arttırır $(p=0.005)$, klyafetlerin 60-90 derecede yıkanması yeni tip koronavirüsün yayılımını engeller $(p=0.000)$, havlu gibi kisisel esyalar ortak kullanıldığı zaman yeni tip koronavirüs yayılımı $\operatorname{artar}(p=0.031)$ sorularını bilme oranı kadınlarda erkeklere göre istatistiksel olarak anlamlı ve yüksek bulunmustur (Tablo 5).

Tablo 6'da COVID-19 için dünyada alınan önlemlere karșı algilanan endișe düzeyi kadınlarda $(p=0.000)$, Türkiye'de alınan önlem yeterliliği algilama düzeyi ortalaması ise erkeklerde daha yüksek ve istatistiksel olarak anlaml bulunmuștur $(p=$ 0.003). Dünyada alınan önlem yeterliliği 1 . sınıflarda 2. siniflara göre daha yüksek ve istatistiksel olarak anlamlı bulunmuștur $(p=0.044)$. Türkiye'de alınan önlem yeterlilik düzeyi sağllk meslek lisesi mezunlarında diğer lise mezunlarına göre istatistiksel olarak anlamlı ve daha yüksek bulunmustur $(p=0.033)$. Kronik hastalık varlığ katılımcıların COVID-19 önlem ve endișe algılarında anlamlı bir etki olușturmamıștır.

\section{TARTIȘMA}

Sağlık çalıșanlarının COVID-19 gibi pandemik hastalıklara karșı davranıs, endișe ve bilgi düzeyleri gibi farkındalıklarının belirlenmesi bu hastalıklara karșı uygun önlem alınması ve yeterli müdahale sağlanabilmesi için hayati bir önem tașımaktadır ${ }^{[14]}$. Sağlık calıșanları infekte hastalarla yakın temasta bulundukları için yüksek düzeyde infeksiyon riskine maruz kalmakta ve hastalığın yayılmasına 


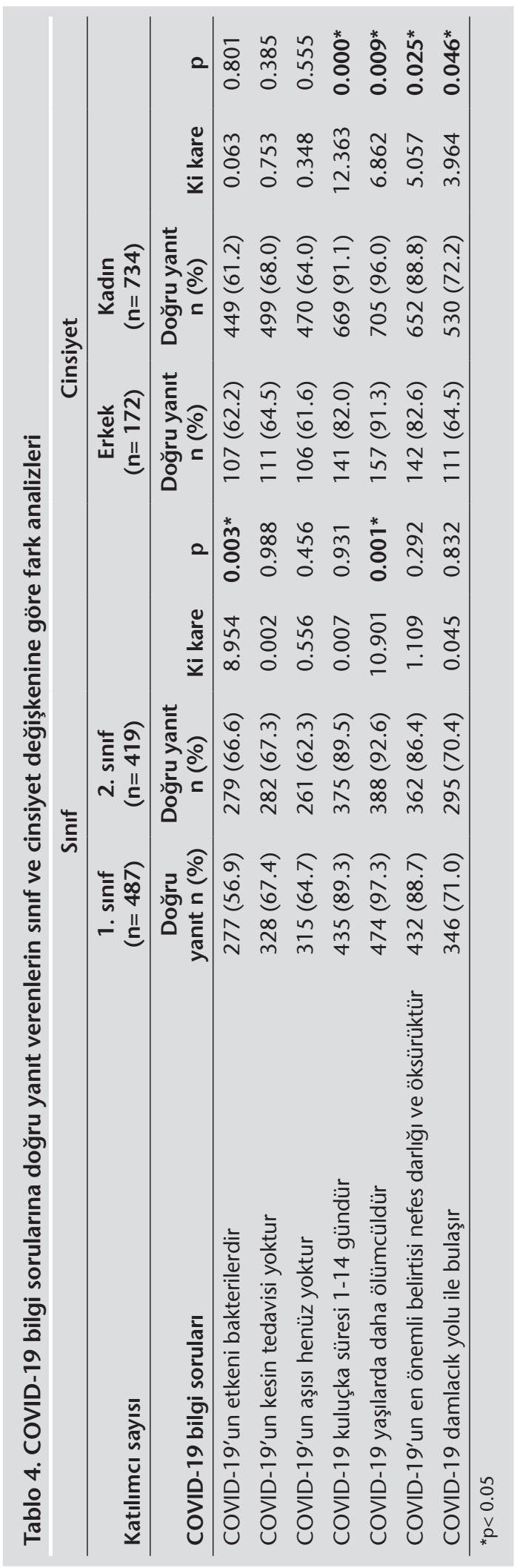

da katkıda bulunmaktadır. Nguyen ve arkadașları (2020), sağlık calıșanlarında COVID-19 test pozitifliği oranının, toplumun geneline göre 11 kat daha yüksek olduğunu bildirmișlerdir ${ }^{[15]}$. Calıșmamızda sağlık teknikeri adaylarının COVID-19 salgını ve korunma yolları ile ilgili yüksek bilgi ve tutuma sahip oldukları tespit edilmiștir (Tablo 2). Bunun nedeni, sağlık teknikeri adaylarına ait eğitim çıtılarının etkili ve yeterli olması olabilir. Kim ve arkadașlarının (2016), Güney Kore'de hemșirelik öğrencilerinin koronavirüs ile ilgili bilgi düzeyleri ve koruyucu davranıș puanlarını çalıșmamızla uyumlu olarak yüksek bulmustur ${ }^{[16]}$.

Araștırmamızda sağlık teknikeri adaylarının \%80.3'ünün COVID-19'u oldukça tehlikeli bulduğu (10 üzerinden 8.03) ve pandemiyle ilgili oldukca yüksek oranda (\%72.7) endiseli oldukları (10 üzerinden 7.27) tespit edilmiștir (Tablo 2). Kim (2017) hemșirelik öğrencilerinin Ortadoğu Solunum Yetmezliği Sendromu (Middle East Respiratory Syndrome: MERS)'nu orta düzeyde tehlikeli gördüğünü bildirmiștir (5 üzerinden 2.4$)^{[17]}$. Choi ve Kim (2016) ise hemșirelik öğrencilerinin MERS bilgi puanlarının 100 üzerinden 81.8, MERS önleyici davranıs ortalamalarının 10 üzerinden 4.51 bulmustur ${ }^{[18]}$. Almutairi ve arkadașları (2015) ise halkın koronavirüse karșı endișe düzeyini çalıșmamızla uyumlu olarak oldukça yüksek bulmuştur ${ }^{[19]}$. Calıșmamızda salgınla ilgili endișe ve tehlike düzeylerinin yüksek görülmesinin sebebinin COVID-19'un dünya çapında pandemi olarak ilan edilmesi olduğu düșünülmektedir. Ayrıca çalıșmamızda sağlık teknikeri adayları, Türkiye'de alınan önlemlerin dünyada alınan önlemlerden daha yeterli olduğunu düșünmektedir. Ülkemizde alınan önlemlerin adayları hastalığa karșı daha az endiselendirdiği de calıșmamızda belirlenmiștir (Tablo 3). Vartti arkadașları (2009), Finlandiya halkının siddetli akut solunum yolu sendromu (Severe Acute Respiratory Syndrome: SARS) hakkında ülkelerine son derece güvendiği ve bunun sebebinin medya kaynaklı olduğunu bildirmistirir ${ }^{[20]}$. Calıșma sonuclarımız literatürle uyumlu olup, Türkiye'nin COVID-19 pandemisinin en son görüldüğü ülkelerden biri olması, medya aracilığıla sıklıkla bilgi paylașımı yapılması, Türkiye'de yayılmadan önce pandemi için önlem alınmaya bașlanması adaylara bu konuda güven vermis olabilir. 


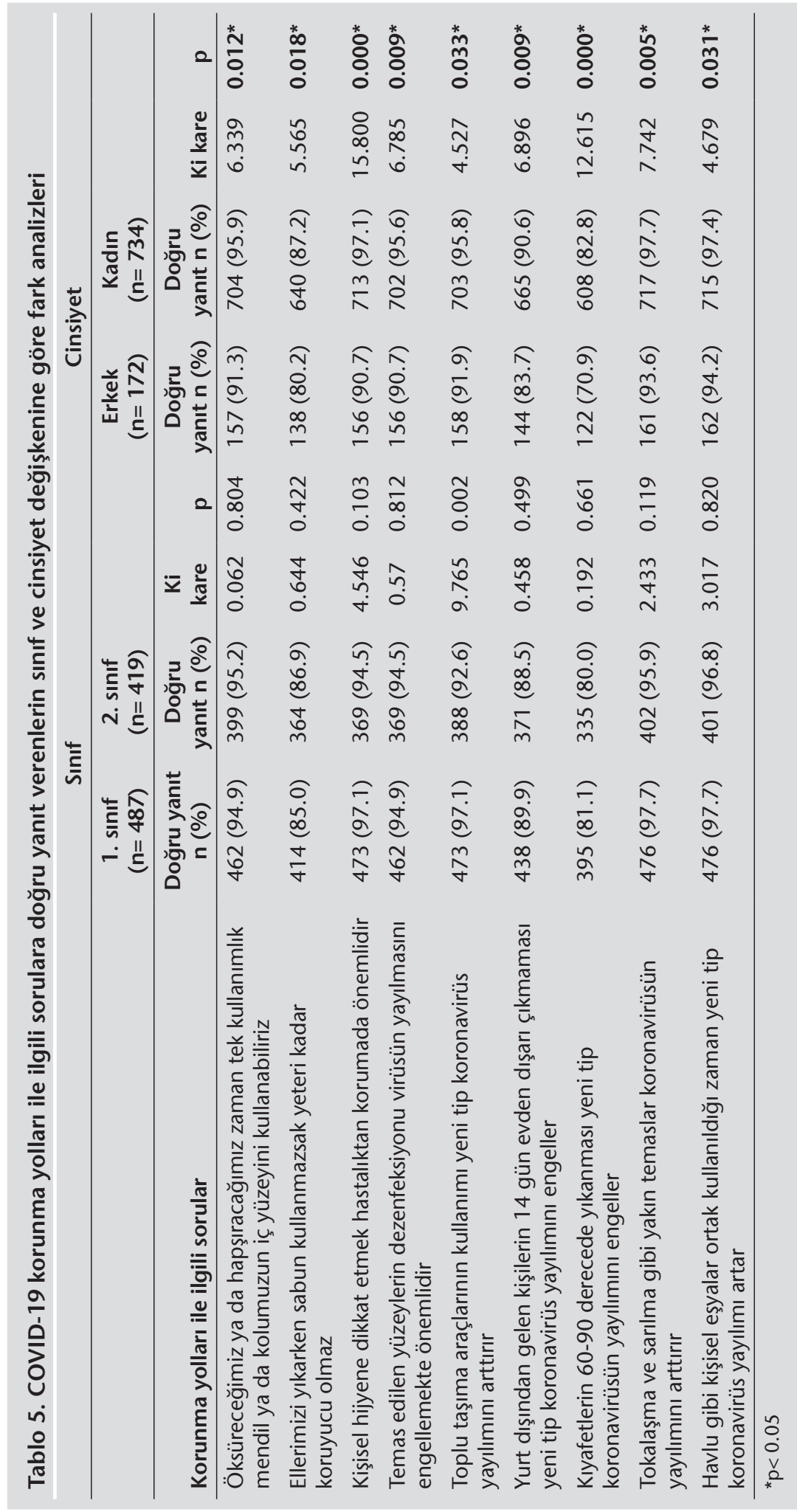




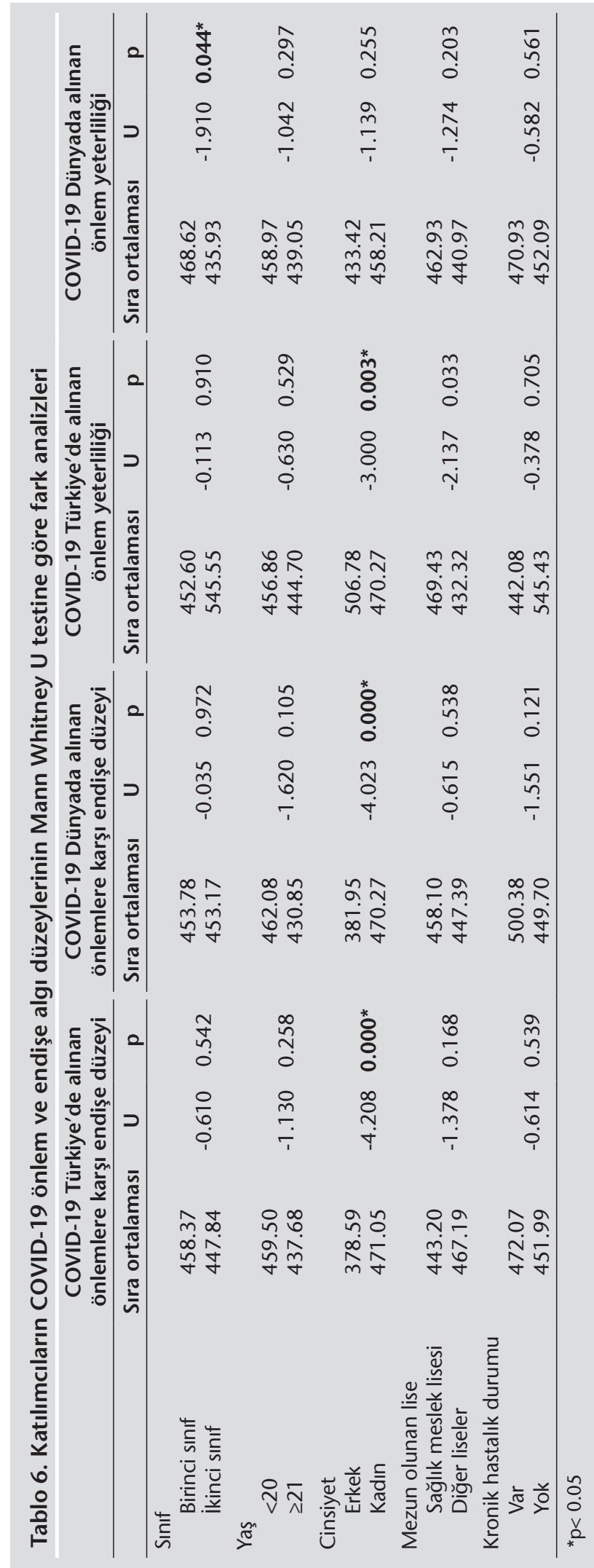


Araștırmamızda COVID-19 bilgi puanı ve korunma yolları puanı arasında pozitif yönlü korelasyon bulunmustur (Tablo 3). Dolayisıyla hastalık hakkındaki bilginin artması ile hastalıktan nasıl korunması gerektiğine yönelik tutum da o yönde artmaktadır. Bu sonuçlar literatürdeki koronavirüs, MERS ve SARS calıșmalarıyla uygunluk göstermektedir ${ }^{[17-20,21]}$. Ayrıca adayların COVID-19 bilgi ve korunma yollarına yönelik puanları ile COVID-19'u tehlikeli görmeleri ve endișe düzeyleri arasında da pozitif korelasyon bulunmustur (Tablo $3)$. $\mathrm{Bu}$ sonuçar da literatüre uygundur ${ }^{[17,18,22]}$. Mevcut sonuclara göre bilgi ve korunma yolları puanları arttıkça dünyada alınan önlemler daha yetersiz görülmektedir.

COVID-19 ile ilgili bilgi ve korunma yolları sorularının çoğuna kadınlar anlamlı olarak doğru yanit vermistir (Tablo 4 ve Tablo 5). Huynh ve arkadașlarının (2020) sağlık calısanlarıyla ve Abdelhafiz ve arkadașlarının (2020) Mısır'da öğrenciler ile yapmıs olduğu araștırmalarda COVID-19 ile ilgili hem bilgi hem de tutum sorularna verilen yanıtlarda kadın katılimclar erkeklere göre daha yüksek puan almıs ancak istatistiksel olarak anlamlı bir fark bulunamamıștır ${ }^{[23,24]}$. Ergün ve arkadașlarının (2020) ambulans servisi çalıșanları ile yapmıs olduğu araștırmada ise COVID-19 ile ilgili bilgi düzeyinde cinsiyetler arası farkllık yok iken, korunma yolları konusunda kadınlar anlamlı olarak erkeklerden daha yüksek puana sahip bulunmustur ${ }^{[25]}$. Yapilan calıșmaların bizim çalıșmamızdan farklllık göstermesinin temel nedeni arastırmalardaki örneklem değișkenliği olduğunu düșünüyoruz. Ayrıca çalıșmamızda bilgi ve koruma düzeyi sorularına verilen doğru yanıtların anlamlllık göstermesinin $(p<0.05)$ temel sebebi, pandemi sürecinde Sağlık Bakanlığının medya aracılı etkili ve yeterli bilgilendirme yapması olabilir.

Araștırmamızda birinci sınıf öğrencileri ikinci siniftakilere göre dünya çapında alınan önlemleri daha yeterli bulmaktadır (Tablo 6). Bunun sebebi birinci sınıfların COVID-19 pandemi bilgi puanlarını daha düsüuk olması olabilir. Bu öğrencilerin alınacak önlemler konusunda bilgi düzeyleri daha düșük olduğu için alınan önlemleri daha yeterli görmüs olabilirler. Park ve arkadașlarının (2018) hemșirelik öğrencilerinin koronavirüs iinfeksiyonu bilgi tutumuyla ilgili yaptığı calıșmada, hazırlık sınıfında bulunan öğrencilerin koronavirüs bilgi düzeylerini diğer üst sıniflardan daha düșük bulmuștur $^{[21]}$. Bizim sonuçlarımızda da COVID-19 etkenini doğru bilme oranı ikinci sınıfta öğrenim gören katılımcılarda anlamlı olarak daha yüksektir. Bu durum ikinci sınıfların almıs olduğu sağlık eğitimi dikkate alındığında beklenen bir sonuc oluşturmus ve literatüre uygunluk göstermiștir. Ayrıca çalısmamızda kadın sağlık teknikeri adaylarının COVID-19 endișe düzeyleri erkeklere göre daha yüksek bulunmuștur (Tablo 6). Bunun sebebi, kadınların Türkiye'de alınan önlem yeterliliğini daha düsüu bulmaları ve hastalıkla ilgili bilgi ve korunma yolları düzeylerinin daha yüksek olması olabilir. Literatürde kadınların koronavirüs, MERS, ve SARS hastalıklarıyla ilgili endișe düzeylerini daha yüksek bulan çalıșmalar mevcuttur [7,9,16,21,22]. Kronik hastalığı olanların da COVID-19 ile ilgili endișe düzeyi daha yüksek cıkmıștır (Tablo 6). Bu sonuc Srichan ve arkadașlarının (2020) sonuçlarıyla benzerlik göstermektedir ${ }^{[7]}$. Bu durumun nedeni pandeminin kronik hastalığ bulunanlarda mortalite oranını arttırması ile bağlantılı olabilir ${ }^{[8]}$.

Araștırmamızda, cevrimiçi ortamda yapılan anket çalıșmasının iki önemli kısıtllığı bulunmaktadır. Birincisi anket formu uygulanmasindan kaynaklanan katılımcilar tarafından anlașılmayan soruları açıklayamama ve katılımcılardan doğru yanıt alma olasılığının düsüuk olma durumudur ${ }^{[13]}$. İkincisi ise araștırmanın sadece bir yüksekokul ile sınılandırılmıs olmasıdır.

Sonuc olarak, araștırmamıza katılan sağlık teknikeri adaylarının COVID-19 hakkında iyi bir bilgi düzeyine sahip oldukları ve bu pandemik hastalık için alınması gereken önlemlerle ilgili yüksek farkındalıkları olduğu tespit edilmiștir. Bununla birlikte genel olarak adayların pandemi ile ilgili endișe düzeyleri özellikle kronik hastalığ olanlarda ve kadınlarda daha fazla bulunmustur. Fakat adaylar Türkiye'de alınan önlemleri dünyadakinden daha yeterli görmüștür. Adaylar bu açıdan ülkemizin sağlı politikalarına ve pandemi ile ilgili alınan önlemlere güvenmektedir. Araștırmanın sadece Gazi Üniversitesi yüksekokulunda sağlık teknikeri adaylarına yapılmıs olması çalıșma sonuçlarını ülke genelinde genelleștirmese de, bu çalıșma ülkemizde bu konuda daha kapsamlı calıșmaların yapilması gerektiğini ortaya koymaktadır. Pandemik hastalık- 
lara yönelik farkındalık calıșmalarının, COVID-19 salgınının önlenebilmesi için sağlık çalıșanlarının bilgi ve endișe düzeylerini ölçmede önemli olduğunu ve bu çalıșmaların ülkemizin pandemik hastalıklar ile ilgili daha ciddi sağlık politikası geliștirmesine ve halk sağlığı uygulamalarına katkı sağlayacağını düșünmekteyiz.

\section{ETIK KURUL ONAYI}

Çalıșma için Gazi Üniversitesi Klinik Olmayan Araștırmalar Etik Kurulundan onay alındı (Karar No: 91610558-604.01.02, Tarih: 07.04.2020).

\section{ÇIKAR ÇATIŞMASI}

Yazarlar bu makale ile ilgili herhangi bir cıkar çatıșması bildirmemișlerdir.

\section{YAZAR KATKISI}

Anafikir/Planlama: EBB, TDT, IC̣

Analiz/Yorum: EBB, TDT

Veri Sağlama: EBB, İC

Yazım: EBB, TDT, İC

Gözden Geçirme ve Düzeltme: EBB, TDT, İC

Onaylama: $\mathrm{EBB}$

\section{KAYNAKLAR}

1. Sahin AR, Erdogan A, Mutlu Agaoglu P, Dineri Y, Cakirci AY, Senel ME, et al. 2019 novel coronavirus (COVID-19) outbreak: A review of the current literature. EJMO 2020;4(1):1 7.

2. Xu L, Liu J, Lu M, Yang D, Zheng X. Liver injury during highly pathogenic human coronavirus infections. Liver Int 2020;40(5):998-1004.

3. Alp Ş, Ünal S. Yeni koronavirüs (SARS-CoV-2) kaynaklı pandemi: Gelişmeler ve güncel durum. Flora 2020;25: 1-10.

4. Singhal T. A review of coronavirus disease-2019 (COVID-19). Indian J Pediatr 2020;87:281-6.

5. Karcıoğlu Ö. COVID-19: Epidemiyolojik bilgilerimiz ve hastalığın dünyadaki gidişi. Journal of ADEM 2020;1(1):55-71.

6. World Health Organization (WHO). Weekly operational update on COVID-19. Available from: https://www.who. int/publications $/ \mathrm{m} /$ item/weekly-operational-update-on-covid-19---6-november-2020. Accessed date: 06 November 2020.

7. Srichan P, Apidechkul T, Tamornpark R, Yeemard F, Khunthason S, Kitchanapaiboon S, et al. Knowledge, attitude and preparedness to respond to the 2019 novel coronavirus (COVID-19) among the bordered population of Northern Thailand in the early period of the outbreak: A cross-sectional study. Lancet 2020.
8. Surveillances V. The epidemiological characteristics of an outbreak of 2019 novel coronavirus diseases (COVID-19)-China. China CDC Weekly 2020;2(8):113-22.

9. Zhong BL, Luo W, Li HM, Zhang QQ, Liu XG, Li WT, et al. Knowledge, attitudes, and practices towards COVID-19 among Chinese residents during the rapid rise period of the COVID-19 outbreak: a quick online cross-sectional survey. Int J Biol Sci 2020;16(10):1745-52.

10. Sağlık Bakanlı̆̆ı Koronavirüs Rehberi. Accessed date: 07 November 2020. Available from: https://covid19.saglik. gov.tr/TR-66393/covid-19-salgin-yonetimi-ve-calisma-rehberi.html

11. Hoda J. Identification of information types and sources by the public for promoting awareness of Middle East respiratory syndrome coronavirus in Saudi Arabia. Health Educ Res 2016;31(1):12-23.

12. Asaad AM, El-Sokkary RH, Alzamanan MA, El-Shafei M. Knowledge and attitudes towards Middle East respiratory syndrome-coronavirus (MERS-CoV) among health care workers in south-western Saudi Arabia. East Mediterr Health J 2020;26(4):435-42.

13. Aksakoğlu G. Sağlıkta Araştırma ve Çözümleme. 2. Baskı. Izmir: Dokuz Eylül Üniversitesi Yayınevi, 2006.

14. Alsubaie S, Hani Temsah M, Al-Eyadhy AA, Gossady I, Hasan GM, Al-Rabiaah A, et.al. Middle East Respiratory Syndrome Coronavirus epidemic impact on healthcare workers' risk perceptions, work and personal lives. I Infect Dev Ctries 2019;13(10):920-6.

15. Nguyen $L H$, Drew $D A$, Graham $M S$, Joshi $A D, G u o C H, M a$ $W$, et al. Risk of COVID-19 among front-line health-care workers and the general community: a prospective cohort study. Lancet Public Health 2020;5(9):475-83.

16. Kim OS, Oh JH, Lee KH. The convergence study on anxiety, knowledge, infection possibility, preventive possibility and preventive behavior level of MERS in nursing students. I Korea Convergence Society 2016;7(3): 59-69.

17. Kim MJ. The convergence study of nursing students' knowledge, attitudes and preventive behaviors against MERS in South Korea. J Korea Convergence Society 2017;8(4):149. 57.

18. Choi JS, Kim JS. Factors influencing preventive behavior against Middle East respiratory syndrome-coronavirus among nursing students in South Korea. Nurse Education Today 2016;40:168-72.

19. Almutairi KM, Al Helih EM, Moussa M, Boshaiqah AE, Saleh Alajilan A, Vinluan JM, et al. Awareness, attitudes, and practices related to coronavirus pandemic among public in Saudi Arabia. Fam Community Health 2015;38(4):332-40.

20. Vartti $A M$, Oenema $A$, Schreck $M$, Uutela $A$, de Zwart $O$, Brug J, et al. SARS knowledge, perceptions, and behaviors: a comparison between finns and the dutch during the SARS outbreak in 2003. Int J Behav Med 2009;16:41-8. 
21. Park JH, Chang SI, Choi S. Correlation between knowledge, attitude, and compliance of preventive behaviors regarding Middle East Respiratory Syndrome among nursing students. J Korean Biol Nurs Sci 2018;20(4):252-260.

22. Brug J, Aro AR, Oenema A, De Zwart O, Richardus JH, Bishop GD. SARS risk perception, knowledge, precautions, and information sources, the Netherlands Emerg Infect Dis 2004;10(8):1486-9.

23. Huynh G, Nguyen TN, Tran VK, Vo KN, Vo VT, Pham LA. Knowledge and attitude toward COVID-19 among healthcare workers at district 2 hospital, Ho Chi Minh City Asian Pac J Trop Med 2020;13:260-5.

24. Abdelhafiz AS, Mohammed Z, Ibrahim ME, Ziady HH, Alorabi $M$, Ayyad $M$, et al. Knowledge, perceptions, and attitude of egyptians towards the novel coronavirus disease (COVID-19). J Community Health 2020;1-10.
25. Ergün E, Ergün S, Çelebi i. Acil sağlık hizmetleri personellerinin COVID-19 hakkında bilgi, korunma düzeyleri ve etkileyen etmenler. Paramedik ve Acil Sağlık Hizmetleri Dergisi 2020;1(1):16-27.

\section{Yazıșma Adresi/Address for Correspondence}

Dr. Öğr. U̇yesi Elif Burcu BALI

Gazi Üniversitesi Sağlık Hizmetleri Meslek Yüksekokulu, Tibbi Hizmetler ve Teknikler Bölümü,

Tibbi Laboratuvar Teknikleri Programı, Ankara-Türkiye

E-posta: burcubali@gazi.edu.tr, e.burcubali@gmail.com 